\title{
Submergence sensitivity of durum wheat, bread wheat and barley at the germination stage
}

\author{
Iduna Arduini, ${ }^{1}$ Cecilia Orlandi, ${ }^{1}$ Laura Ercoli, ${ }^{2}$ Alessandro Masoni ${ }^{1}$ \\ ${ }^{1}$ Department of Agriculture, Food and Environment, University of Pisa; ${ }^{2}$ Scuola Superiore \\ Sant'Anna, Pisa, Italy
}

\begin{abstract}
Soil waterlogging at initial growth stages can cause heavy yield losses of winter cereals. Therefore, the screening for submergence tolerance traits in seeds of commercial varieties is of high concern worldwide. Ten Italian varieties of durum wheat (Triticum durum Desf.), bread wheat (T. aestivum L.) and barley (Hordeum vulgare L.) were investigated for their ability to germinate in submerged conditions and to recover after submergence periods of three to 15 days. Submergence prevented germination and decreased germinability, at rates that increased with duration of submergence. Sensitivity ranked in the order: barley >durum wheat > bread wheat. We related the higher sensitivity of barley to its slower germination and slightly higher leakage of electrolytes, whereas the percentage of abnormal seedlings was lower than in other species. It was less than $4 \%$, compared to less than 15 and $8 \%$ in durum wheat and bread wheat, respectively. Wide varietal differences were found in all species. According to variety, after 6-day submergence, germinability ranged from 2 to $42 \%$ in barley, from 5 to $80 \%$ in durum wheat, and from 30 to $77 \%$ in bread wheat. Varieties with more than $40 \%$ seed survival were three, six and seven per species, in the same order. The differential submergence sensitivity of varieties indicates a potential to select for waterlogging tolerance within Italian genotypes of winter cereal crops.
\end{abstract}

Correspondence: Alessandro Masoni, Department of Agriculture, Food and Environment, University of Pisa, via del Borghetto 80, 56124 Pisa, Italy. Tel.: + 39.050.2218935.

E-mail: alessandro.masoni@unipi.it

Key words: Germination; varietal screening; waterlogging sensitivity; winter cereals.

Received for publication: 28 July 2015

Revision received: 27 February 2016.

Accepted for publication: 27 February 2016.

(C) Copyright I. Arduini et al., 2016

Licensee PAGEPress, Italy

Italian Journal of Agronomy 2016; 11:706

doi:10.4081/ija.2016.706

This article is distributed under the terms of the Creative Commons Attribution Noncommercial License (by-nc 4.0) which permits any noncommercial use, distribution, and reproduction in any medium, provided the original author(s) and source are credited.

\section{Introduction}

According to Food and Agriculture Organisation (FA0), approximately $10 \%$ of the global land area is affected by waterlogging, which significantly reduces yield of cereal crops in many regions of the world (Hossain and Uddin, 2011; Li et al., 2011). In the Mediterranean area winter cereal crops are at risk of waterlogging especially at initial growth stages, because approximately $40 \%$ annual rainfall concentrates in autumn, in coincidence with their optimal sowing time (Bassu et al., 2009). Since rainfall intensity is expected to increase in the future (Brunetti et al., 2000), the screening for waterlogging tolerance traits in seeds of commercial varieties is of high concern.

Waterlogging causes the early depletion of oxygen from the soil water, which takes place within a few hours after soil has been saturated (Singh and Singh, 2003; Hossain and Uddin, 2011). While oxygen concentration falls, concentrations of carbon dioxide and ethylene increase, and changes occur in soil bacteria populations, leading to an intense de-nitrification and accumulation of ammonium and polyphenolic compounds (Unger et al., 2010; Hamonts et al., 2013). Some nutrients, primary nitrogen, become less available, while others increase their availability up to toxic levels (Colmer and Greenway, 2011).

Germination is a very crucial step in plant life and, in most species, prolonged seed imbibition under submergence induces the leakage of potassium and phosphate, as well as the diffusion of carbohydrates and amino acids, causing seedling starvation and the proliferation of pathogenic microorganisms (Menegus et al., 1991; Hsu et al., 2000; Tajbakhsh, 2000). Moreover, the accumulation of fermentation ethanol disrupts mitochondrial membranes leading to self-poisoning (Crawford, 1977).

When submerged just after seeding, the major cultivated cereal crops fail to germinate and loose their viability, resulting in poor crop establishment, though wide genetic variation was found in the response of varieties (Fausey and McDonald, 1985; Hsu et al., 2000; Setter and Waters, 2003; El-Hendawy et al., 2011; Kirmizi and Bell, 2012). In rice, tolerant genotypes showed more rapid water absorption and germination, both in aerobic and anaerobic conditions (ElHendway et al., 2011). At low oxygen levels, they also increased ethylene production, which enhanced coleoptile extension, so to enable seedlings to gain access to the atmosphere (Magneschi and Perata, 2009). The primary cause of the higher waterlogging sensitivity of wheat and barley compared to rice is that seeds are not able to degrade starch under anoxia and consume rapidly soluble sugars through fermentation (Guglielminetti et al., 2001). Nevertheless, modern barley genotypes from northern Europe were found to display higher waterlogging tolerance than older ones, which was interpreted as an inadvertent adaptation to increased precipitation (Bertholdsson, 2013). In wheat, barley and triticale, a certain waterlogging tolerance at germination and initial seedling stages was associated with high seed mass and with the ability to form adventitious roots (Singh and Singh, 2003; Pang et al., 2007; Hossain and Uddin, 2011). 
Taking into account that climatic trends will increase the exposure of winter cereal crops to soil waterlogging during germination, and that traits of tolerance have been evidenced across genotypes of several cereals, we tested a wide range of Italian commercial varieties of durum wheat, bread wheat and barley for their ability: i) to germinate in submerged conditions; and ii) to recover from periods of submergence of different length.

\section{Materials and methods}

\section{Plant materials}

Ten varieties of durum wheat (Triticum durum Desf.), bread wheat (T. aestivum L.) and barley (Hordeum vulgare L.), chosen among genotypes currently cultivated in Italy, were tested (Table 1). Seeds obtained from commercial sources were stored in a refrigerator at $4^{\circ} \mathrm{C}$ until use, which occurred within a year from harvest. Mean weight and water content were measured for the seed pool of each variety, the former on fresh weight basis, the latter after drying for $2 \mathrm{~h}$ at $130^{\circ} \mathrm{C}$ (ISTA, 2004). Mean kernel weight of all varieties was reported in Table 1. Water content did not vary significantly among varieties and was $10.7 \%[ \pm 0.28$ standard error (SE)] in durum wheat, $9.8 \%( \pm 0.29 \mathrm{SE})$ in bread wheat and $9.0 \%( \pm 0.45 \mathrm{SE})$ in barley. Germinability was determined at $20^{\circ} \mathrm{C}$ in the dark (ISTA, 2004), and ranged from 87 to $98 \%$.

\section{Seed submergence and recovery}

Submergence and germination tests were carried out in germination cabinets. Seeds were submerged in 14-cm-diameter glass Petri dishes, filled with $150 \mathrm{~mL}$ of sterilized deionized water $(\mathrm{pH} 5.9$; electrical conductivity $2.2 \mu \mathrm{S} \mathrm{cm}-1$ ), and enveloped in aluminium foil to minimize gas exchange. Submergence treatments were three (S3), six (S6), nine (S9), 12 (S12) and 15 (S15) days at $20^{\circ} \mathrm{C}$ constant temperature in the dark. At the end of submergence, incubation solutions were collected and seeds were carefully transferred to glass Petri dishes $(9-\mathrm{cm}-$ diameter) containing one layer of Whatman No. 1 filter paper mois-

Table 1. Genetic background, year of release (year), mean kernel weight and germinability at $20^{\circ} \mathrm{C}$ in the dark of the genotypes grouped into submergence sensitivity classes.

\begin{tabular}{|c|c|c|c|c|c|c|}
\hline Species & Sensitivity class & Genotype & Genetic background & Year & MKW (mg) & GP $(\%)$ \\
\hline Triticum durum & $\begin{array}{l}\text { I } \\
\mathrm{GP}<10 \% \text { at } \mathrm{S} 6\end{array}$ & $\begin{array}{l}\text { Anco Marzio } \\
\text { Baio } \\
\text { Hathor } \\
\text { Levante } \\
\text { Claudio } \\
\text { Maestrale } \\
\text { Normanno } \\
\text { Saragolla } \\
\text { Svevo } \\
\text { Dylan }\end{array}$ & $\begin{array}{l}\text { Stot/Altar84/ALD } \\
\text { Duilio/F21/G76 } \\
\text { not available } \\
\text { G80/Piceno//onio } \\
\text { Cimmyt35/Durango/IS1938/Grazia } \\
\text { Iride/Svevo } \\
\text { Simeto/F22/L35 } \\
\text { Iride/PSB 0114 } \\
\text { Linea Cimmyt/Zenit } \\
\text { Neodur/Ulisse }\end{array}$ & $\begin{array}{l}2003 \\
1998 \\
2006 \\
2002 \\
\\
1998 \\
2004 \\
2002 \\
2004 \\
1996 \\
2002\end{array}$ & $\begin{array}{l}49.9 \\
55.0 \\
46.3 \\
47.6 \\
\\
51.1 \\
46.7 \\
55.8 \\
45.9 \\
52.7 \\
39.9\end{array}$ & $\begin{array}{l}95.3 \\
96.7 \\
90.0 \\
88.7 \\
\\
93.3 \\
92.7 \\
91.3 \\
90.0 \\
87.3 \\
89.4\end{array}$ \\
\hline Triticum aestivum & $\begin{array}{l}\text { I } \\
\mathrm{GP}<40 \% \text { at } \mathrm{S} 6 \\
\text { II } \\
\mathrm{GP}>50 \% \text { at } \mathrm{S} 6 \mathrm{GP}<20 \% \text { at } \mathrm{S} 9 \\
\text { III } \\
\mathrm{GP}>40 \% \text { at } \mathrm{S} 9\end{array}$ & $\begin{array}{l}\text { Arezzo } \\
\text { Lilliput } \\
\text { Nomade } \\
\text { Adelaide } \\
\text { Adelante } \\
\text { Albachiara } \\
\text { Antille } \\
\text { Aquilante } \\
\text { Arabia } \\
\text { Blasco }\end{array}$ & $\begin{array}{l}\text { Not available } \\
\text { Tremie/Primoasi } \\
\text { Zena/Soisson } \\
\text { Tremie/Taylor } \\
\text { Not available } \\
\text { BT/Sagittario } \\
\text { Multiple cross } \\
\text { Wild cross } \\
\text { Guadalupe/Tibet } \\
\text { Oderzo/Barra }\end{array}$ & $\begin{array}{l}2008 \\
2007 \\
2003 \\
\\
2007 \\
2009 \\
2004 \\
2006 \\
2006 \\
2009 \\
\\
2002\end{array}$ & $\begin{array}{l}44.4 \\
44.4 \\
45.3 \\
\\
41.6 \\
43.7 \\
53.4 \\
43.9 \\
52.1 \\
42.1 \\
\\
41.5\end{array}$ & $\begin{array}{l}93.3 \\
96.0 \\
89.3 \\
\\
88.0 \\
98.0 \\
89.3 \\
92.7 \\
91.9 \\
95.3 \\
\\
94.0\end{array}$ \\
\hline Hordeum vulgare & $\begin{array}{l}\text { I } \\
\mathrm{GP}<40 \% \text { at } \mathrm{S} 3 \\
\text { II } \\
\mathrm{GP}>50 \% \text { at } \mathrm{S} 3 \\
\mathrm{GP}<20 \% \text { at } \mathrm{S} 6\end{array}$ & $\begin{array}{l}\text { Aldebaran } \\
\text { Atomo* } \\
\text { Campagne } \\
\text { Lutece } \\
\text { Mattina } \\
\\
\text { Amillis* } \\
\text { Arkansas } \\
\text { Pilastro }\end{array}$ & $\begin{array}{l}\text { Rebelle/Jadore } \\
\text { Not available } \\
\text { Carola/Reflex } \\
\text { Not available } \\
\text { Friberga/Express//L40/43 }\end{array}$ & $\begin{array}{l}2003 \\
2009 \\
2007 \\
2003 \\
1998\end{array}$ & $\begin{array}{l}39.4 \\
58.1 \\
42.8 \\
42.3 \\
40.5\end{array}$ & $\begin{array}{l}87.3 \\
93.3 \\
93.3 \\
92.0 \\
88.7\end{array}$ \\
\hline
\end{tabular}

MKW, mean kernel weight; GP, germinability. *spp. distichum. 
tened with $7 \mathrm{~mL}$ of sterilized deionized water. Seeds were allowed to recover for eight days at $20^{\circ} \mathrm{C}$ constant temperature in the dark, and a control (S0), consisting of not submerged seeds, was added for each variety. Dishes were arranged in a randomized block experimental design, with varieties completely randomized within submergence periods, with three replicate dishes, each containing 50 seeds, for all combinations variety $\mathrm{x}$ submergence period.

The number of germinated seeds was recorded at the end of submergence periods and, daily, during the recovery period. Seeds were considered germinated when the radicle and the hypocotyl had emerged for at least $2 \mathrm{~mm}$ length from the seed coat (ISTA, 2004). On the $8^{\text {th }}$ day, abnormal seedlings were counted and not germinated seeds were checked for coat hardiness.

Following Chen et al. (2012), the germination rate index (GRI, number of germinated seeds day ${ }^{-1}$ ) was calculated to express seed vigour during recovery, as: $G R I=\sum G_{t} / t$. In the formula, $G_{t}$ is the number of seeds germinated each day and $t$ the number of days of recovery.

At the end of each submergence period, the $\mathrm{pH}$ was measured by means of a laboratory pH-meter (Crison Basic 20) equipped with a glass electrode for difficult matrices, and the electrical conductivity with a pocket conductivity tester (International PBI, Milan, Italy). Electrical conductivity was expressed on the basis of $1 \mathrm{~g}$ initial seed weight $\left(\mu \mathrm{S} \mathrm{cm} \mathrm{cm}^{-1} \mathrm{~g}^{-1}\right)$, by dividing the measured value by the average weight of 50 seeds (Pekşen et al., 2004).

\section{Statistical analysis}

Analysis of variance was performed separately for each species, to assess whether variety and submergence period significantly affected all measured parameters. Percentage data were arcsine transformed before analysis. Significantly different means were separated at $\mathrm{P} \leq 0.05$ by the Tukey's test (Steel et al., 1997).

\section{Results}

\section{Effect of submergence on seeds}

In all species embryos swelled and perforated seed coats during submergence, but in barley they were all visible after 3-day submergence, in durum wheat after three or six days, and in bread wheat only after six days. Nevertheless, in barley, seeds of none variety completed germination during submergence, in durum wheat, $0.8 \%$ of seeds in the variety Dylan, while in bread wheat $1-2 \%$ of seeds in the varieties Adelante, Albachiara, Aquilante, Blasco, Lilliput and Nomade. After 6day submergence, bubbles and streams or blisters of viscous material started to be visible around seeds, which caused a chalky turbidity of the solution with 9-day or longer submergence.

The $\mathrm{pH}$ of the imbibing solution did not change up to $\mathrm{S} 6$ in wheat species, whereas it increased from 5.9 to 6.6 in barley. In all species it decreased sharply with S9 or longer periods, and measured approximately 5.5 in the former species and 6.2 in the latter (data not shown).

The electrical conductivity of the imbibing solution increased linearly with the duration of submergence, and was slightly higher in barley than in wheat species. Regression coefficients $\left(\mathrm{R}^{2}\right)$ were 0.99 in durum wheat, 0.98 in bread wheat and 0.97 in barley (Figure 1).

\section{Seed performance at recovery}

Following statistical analysis, varieties were separated into three classes based on their germinability after submergence. The most sensitive varieties of each species were assigned to Class I: they showed significantly reduced germinability after 6 -day submergence in durum wheat $(<10 \%)$ and bread wheat $(<40 \%)$, and after only three days in barley (<40\%) (Table 1). Class III varieties maintained germinability higher than $40 \%$ after 9-day submergence in wheat species, and higher than $30 \%$ after six days in barley. Finally, varieties with intermediate sensitivity were assigned to Class II.

\section{Durum wheat}

A 3-day submergence decreased by approximately $15 \%$ seed germinability in Class I and II, but had no effect in Class III (Figure 2). Seeds almost completely lost viability at S6 in Class I and at S9 in Class II, while approximately $15 \%$ of Class III seeds were still viable at S15. The shortest submergence treatment (S3) did not affect the germination rate index during recovery in Class I and II, and increased it by approximately 39\% in Class III (Figure 2). At S6, the germination rate index fell dramatically in the first two classes, while it was still $40 \%$ higher than in controls in Class III. Abnormal seedlings were at maximum 3\% in Class I, 14\% in Class II and 6\% in Class III. Highest values were obtained at increasing submergence length with increasing tolerance: at S3 in Class I, S6 in Class II and S9 in Class III (Figure 2). In general, abnormal seedlings had normally elongated coleoptiles but lacked in roots. At a whole, six varieties out of ten (Claudio, Dylan, Maestrale, Normanno, Saragolla and Svevo) maintained germinability higher than $40 \%$ after 6-day submergence.

\section{Bread wheat}

In this species, germinability was not affected significantly at $\mathrm{S} 3$, whereas, at $\mathrm{S} 6$, it decreased by $68 \%$ in Class I, and by approximately $22 \%$ in Class II and III (Figure 3). Differences among classes were still pronounced at S9, but disappeared with longer periods of submergence. The germination rate index evidenced that 3-day submergence speeded germination in all classes. At S6 the GRI was similar to controls in Class II and III but significantly lower in Class I (Figure 3). The percentage of abnormal seedlings peaked at S6 in Class I and at S9 in the other two classes, with values that were slightly higher in Class II, but never exceeded $8 \%$ (Figure 3). Similar to durum wheat, abnormal seedlings had no roots, while coleoptiles were equal or even longer than those of controls. In bread wheat, seven varieties (Adelaide, Adelante, Albachiara, Antille, Aquilante, Arabia and Blasco) maintained germinability higher than $40 \%$ after 6 -day submergence.

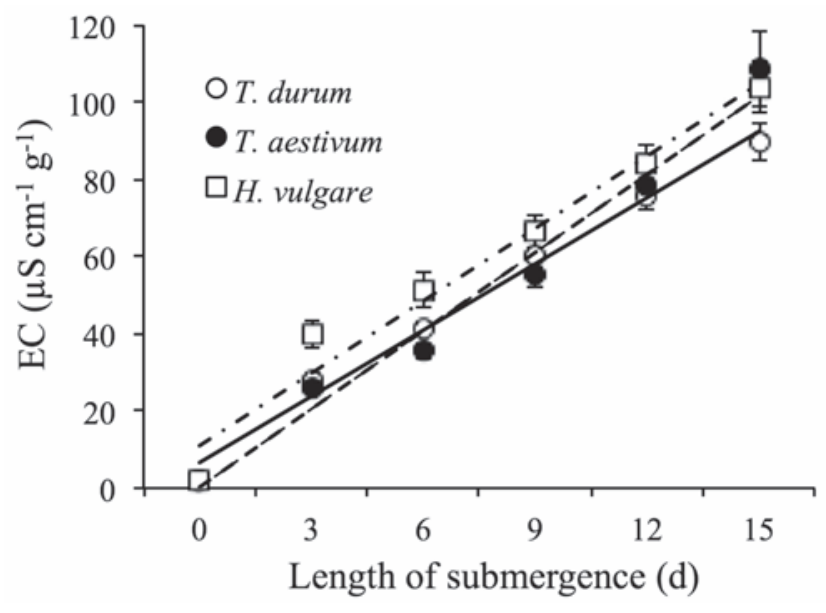

Figure 1. Electrical conductivity (EC) of the imbibing solution after seed submergence. Data are means $\pm S E$ of 10 varieties. Equations of regression lines are: durum wheat, $y=5.7 x+6.6$ (solid line); bread wheat, $y=6.8 x+0.25$ (dashed line); barley, $y$ $=6.3 \mathrm{x}+11$ (dashed-dotted line). 
Barley

Germinability was markedly reduced after only 3-day submergence in all classes: by 64, 27 and 19\%, with decreasing sensitivity (Figure 4). At S6, $43 \%$ of Class III seeds were still viable, but only approximately $7 \%$ of Class I and II seeds. With longer periods of submergence, germina-
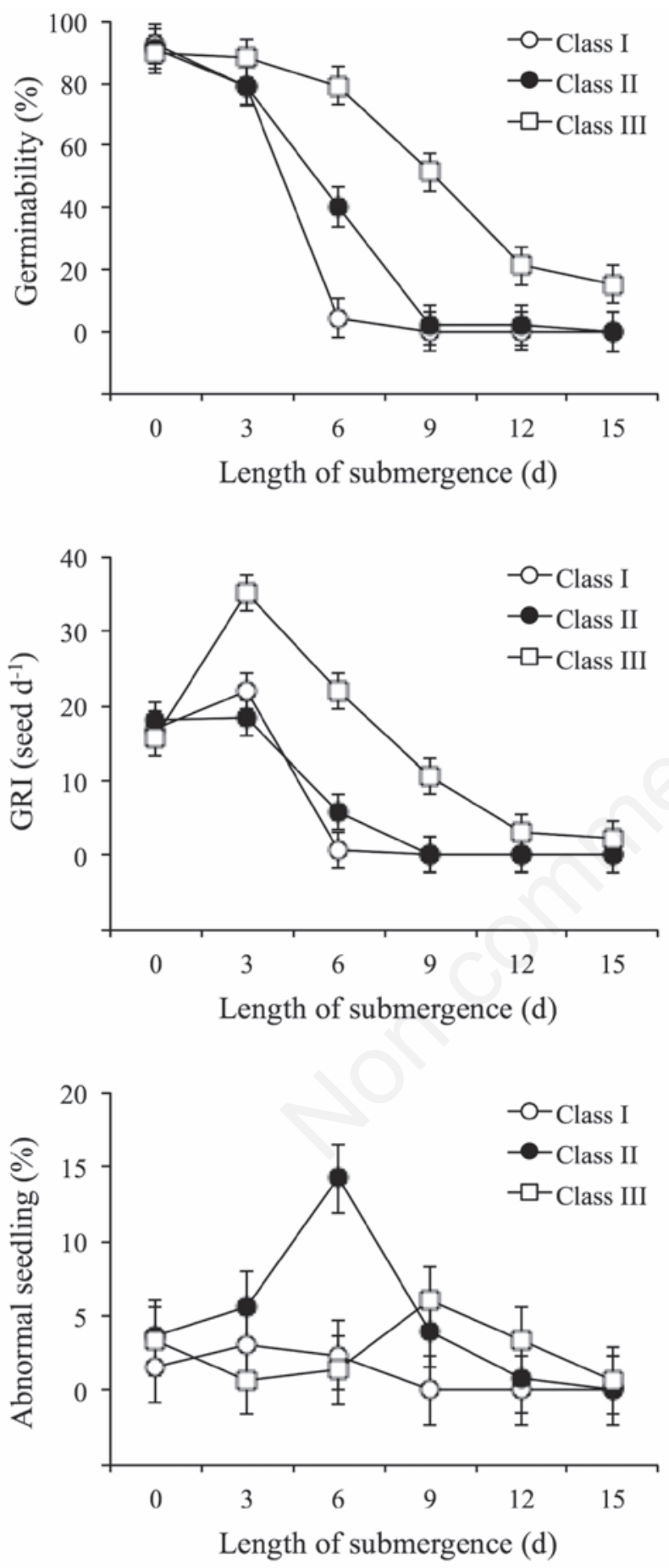

Figure 2. Germinability, germination rate index (GRI) and abnormal seedlings of durum wheat submergence-sensitivity classes, as affected by the length of submergence. Values are means of the varieties belonging to each class and 3 replicates. Vertical bars denote honest significant difference at $\mathbf{P} \leq 0.05$. tion was close to zero in all classes. Seeds of barley started germination one day later compared to those of wheat and, therefore, the germination rate index was markedly lower in this species (Figure 4). Submergence never speeded germination and, in Class I and II, GRI was lower than in controls after only 3 -day submergence. In barley the
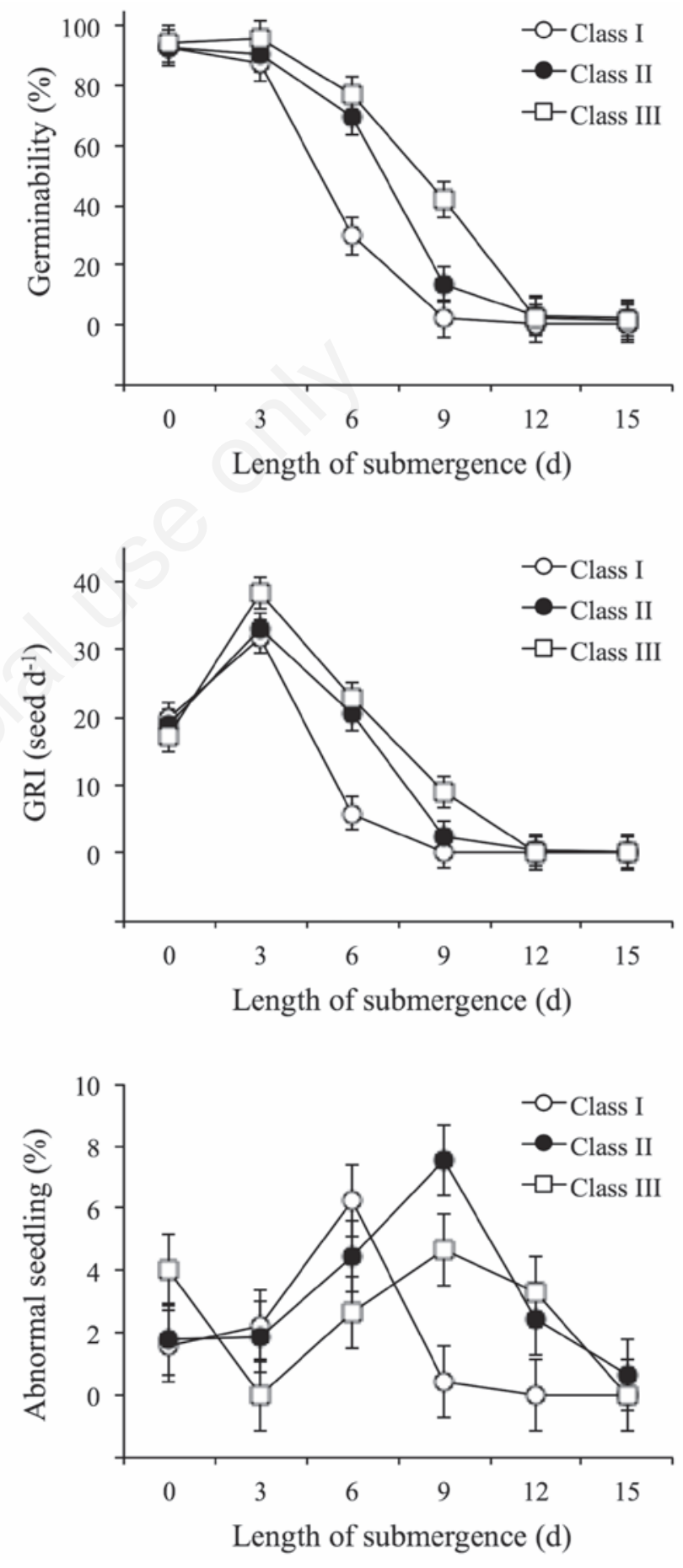

Figure 3. Germinability, germination rate index (GRI) and percentage of abnormal seedlings of bread wheat submergence-sensitivity classes, as affected by the length of submergence. Values are means of the varieties belonging to each class and 3 replicates. Vertical bars denote honest significant difference at $\mathrm{P} \leq 0.05$. 
percentage of abnormal seedlings never exceeded 3.3\% and, in all classes, highest values were recorded in controls and at S6 (Figure 4). It is worth noting that, oppositely to wheat species, abnormal seedlings developed roots but not coleoptiles. In barley, only three varieties (Amillis, Arkansas and Pilastro) maintained germinability higher than $40 \%$ after 6 -day submergence.

\section{Germinability and germination speed relationship}

In wheat species, an asymptotic function linked germinability and germination rate index, while in barley a linear relationship was found (Figure 5). Germinability increased almost linearly with the increase of

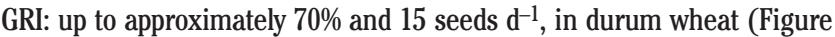
5), up to $80 \%$ germinability and 25 seeds $\mathrm{d}^{-1} \mathrm{GRI}$ in bread wheat (Figure 5) and up to $95 \%$ germinability and 14 seeds $\mathrm{d}^{-1}$ in barley (Figure 5). In wheat species a wide range of GRI corresponded to high germinability because of the differential response of varieties to short submergence periods. Accordingly, the three highest GRI values reported on Figure $5 \mathrm{~A}$ and $5 \mathrm{~B}$ refer to the less sensitive varieties Dylan (durum wheat) and Blasco (bread wheat) at S3.

\section{Discussion}

In all species, we found that submergence prevented germination and progressively decreased germinability, which fell to zero for 9-day or longer treatments. Nevertheless, species differed in sensitivity to submergence, with barley being the most sensitive and bread wheat the least one. Hsu et al. (2000) and Tajbakhsh (2000) reported that the prolonged submergence of wheat and barley seeds caused membrane disruption and the leakage of substances, which was directly correlated with the increase in electrical conductivity and the decrease in seed viability. In the present research, the electrical conductivity of the imbibing solution increased linearly with the duration of submergence, but there was not a direct relationship with seed viability, probably because the loss of substances from seeds continued after their death. Seed death occurred in the range of $50-60 \mu \mathrm{S} \mathrm{cm}^{-1} \mathrm{~g}^{-1}$ in durum wheat and barley, and at approximately $80 \mu \mathrm{S} \mathrm{cm}^{-1} \mathrm{~g}^{-1}$ in bread wheat, which indicates that, oppositely to the findings of Pekşen et al. (2004), higher submergence tolerance was not associated with reduced leakage.

Decreased recovery after submergence was primary due to seed death, since abnormal seedlings accounted for only a small proportion of non-germinated seeds. Consistent to our findings, Shiel et al. (1987) found that, also in the soil, waterlogging decreased emergence by increasing primary seed rotting and only secondly the percentage of damaged seedlings. Abnormal wheat seedlings did not develop roots, suggesting that oxygen shortage during submergence irreparably damaged root growing-points, while coleoptile elongation could be restored during recovery. In contrast, also coleoptile elongation was affected in barley, which, probably, explains the low percentage of abnormal seedlings recorded in this species. According to Perata et al. (1996), wheat and barley seeds kept under anoxia die from sugar starvation because they are not able to degrade starch, and the higher tolerance of Triticum compared to Hordeum probably depends on the higher content in soluble carbohydrate of the former. In Oryza sativa and Triticum spelta, waterlogging tolerance was associated with rapid germination and fast coleoptile elongation, because this enables the seedlings to gain access to atmospheric oxygen (Burgos et al., 2001; Magneschi and Perata, 2009; El-Hendway et al., 2011). Though germination under submergence was negligible in all species, we found an association between sensitivity to submergence and germination speed. Indeed, both in control conditions and during recovery, the germination rate index was markedly lower in the more waterlogging sensitive barley, and, between wheat species, it was slightly lower in durum wheat than in the more tolerant bread wheat. Since embryos of barley swelled faster under submergence, we argue that this species is likely to be more sensitive to submergence for the prompter activation, but slower
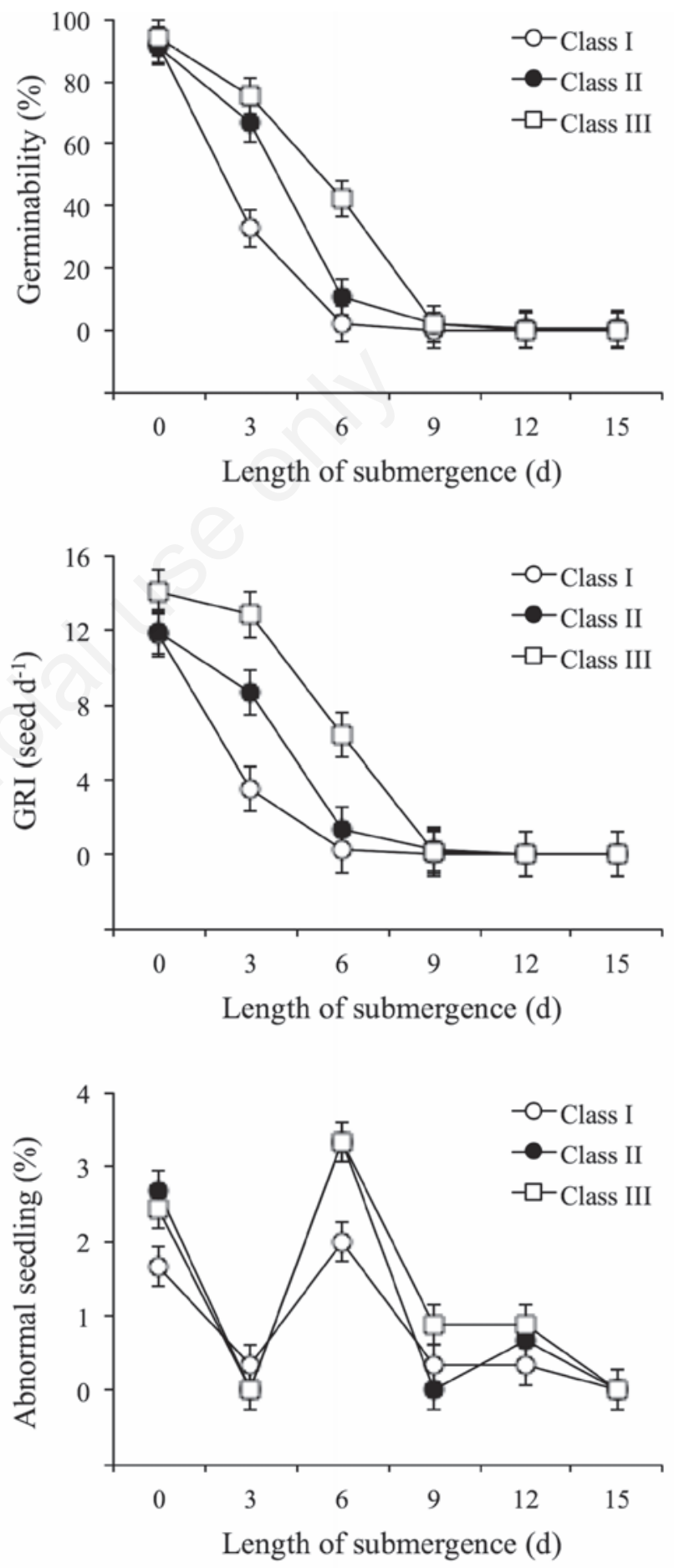

Figure 4. Germinability, germination rate index (GRI) and percentage of abnormal seedlings of barley submergence-sensitivity classes, as affected by the length of submergence. Values are means of the varieties belonging to each class and 3 replicates. Vertical bars denote honest significant difference at $\mathbf{P} \leq 0.05$. 
progress of cell growth processes in anoxic conditions. In support, Perata et al. (1996) found that wheat seeds survived longer than those of barley under anoxia, because of the slower consumption of soluble carbohydrates. In addition at short submergence periods, we found a higher electrical conductivity and a lower germination speed in barley, which is consistent with the hypothesis that essential nutrients are rapidly lost in this species. In contrast, in bread wheat, germination proceeded faster or was not affected after 3-day submergence, suggesting that imbibition proceeded during submergence, without damaging seed metabolism. Durum wheat showed an intermediate behaviour, with some varieties germinating more slowly after short submergence and other faster. In all species we found a close relationship between germinability and germination rate index. This was described by asymptotic functions in wheat species and by a line in barley, probably because, in the former two species, a slight or none decrease in germinability corresponded to an increase or un-change of GRI, while in the latter both parameters decreased in parallel.

Marked varietal differences in the response to submergence were detected in all species and, consistently with their sensitivity ranking, these were largest after shorter submergence in barley (S3 and S6), than in durum wheat (S6) and bread wheat (S6 and S9). Varietal differences indicate that also Italian genotypes of wheat and barley display tolerance traits, as it was reported for genotypes selected in other regions of the world (Musgrave and Ding, 1998; Setter and Waters, 2003). However, oppositely to findings of Singh and Singh (2003), Bertholdsson (2013), and Sultana et al. (2013), within none of the studied species, waterlogging sensitivity of varieties could be related to the year of release or to low seed mass. It is even worth noting that the less sensitive wheat varieties, Dylan (durum wheat) and Blasco (bread wheat), had the lowest mean kernel weight. Finally, in bread wheat, the ability to germinate under submergence was not associated with a specific sensitivity class.

Germination speed in control conditions explained differences in submergence sensitivity among species but not among varieties. Indeed, only in barley the germination rate index was higher in Class III varieties compared to more sensitive classes, while in wheat species it was slightly lower in the most tolerant varieties Dylan and Blasco. It could be that slower germination avoided energy consumption in these varieties, enabling them to germinate promptly during recovery. In agreement, Kong et al. (2010) found that flooded wheat seedlings were able to down-regulate cell metabolism. In wheat species, and especially in durum wheat, the lower germinability of Class II varieties depended primary on the increase of abnormal seedlings with long coleoptiles but without any root. This, along with the observation that submerged seeds often developed roots from a more lateral position of the epiblast node compared to controls, suggests that growing points of seminal root primordia are irreparably damaged during submergence and a successful recovery depends on their number in the embryo. We did not determine the number of seminal roots and therefore we cannot assess if there was an association between this trait and waterlogging tolerance, but Christopher et al. (2013) found that seminal root number shows significant genotypic variation in wheat.

\section{Conclusions}

In conclusion, this research evidenced that all tested species were highly sensitive to submergence at the germination stage, but sensitivity decreased in the order barley, durum wheat and bread wheat. Varietal differences were detected within all species, and according to their sensitivity, the number of varieties with more than $40 \%$ seed survival after 6-day submergence was three, six and seven, respectively.
After 9-day submergence, only one variety showed appreciable survival in each wheat species, and none in barley. The higher sensitivity of barley is likely to depend on the prompter embryo imbibition under submergence associated with slower germination. The differential submergence tolerance of varieties could not be associated with year of

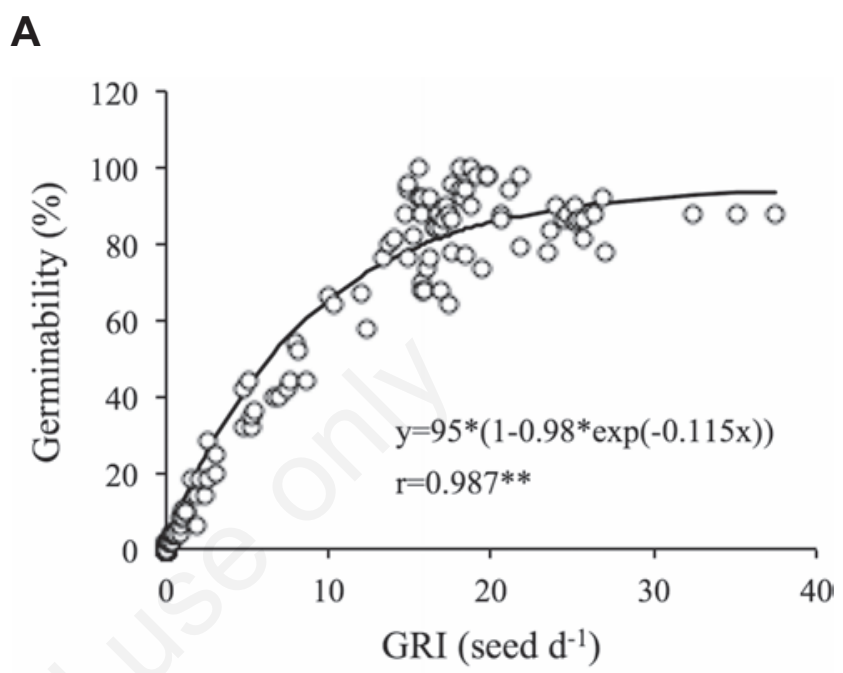

B
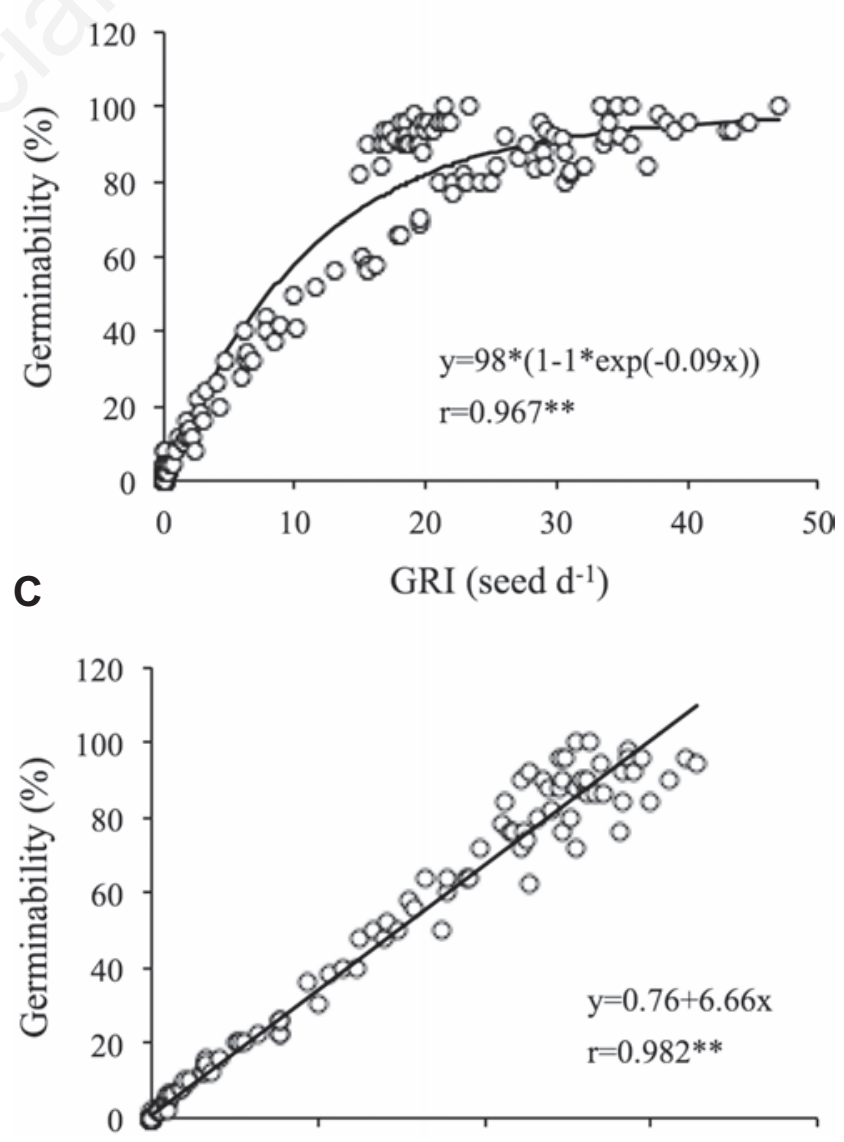

Figure 5. Relationship between geminability and germination rate index (GRI) in durum wheat (A), bread wheat $(B)$ and barley (C); $\mathbf{n}=\mathbf{1 8 0}$. 
release, seed size, leakage of substances, and, except in barley, with germination speed. Accordingly, differences in seed metabolism should be taken into account. We suggest that the preservation of healthy root growing points is critical for recovery from submergence, and further research is needed to assess this point.

\section{References}

Bassu S, Asseng S, Motzo R, Giunta F, 2009. Optimising sowing date of durum wheat in a variable Mediterranean environment. Field Crop Res. 111:109-18.

Bertholdsson NO, 2013. Screening for barley waterlogging tolerance in nordic barley cultivars (Hordeum vulgare L.) using chlorophyll fluorescence and hydroponically-grown plants. Agronomy 3:376-90.

Brunetti M, Buffoni L, Maugeri M, Nanni T, 2000. Precipitation intensity trends in northern Italy. Int. J. Climatol. 20:1017-31.

Burgos S, Stamp P, Schmid JE, 2001. Agronomic and physiological study of cold and flooding tolerance of spelt (Triticum spelta L.) and wheat (Triticum aestivum L.). J. Agron. Crop Sci. 187:195-202.

Chen G, Wang QZ, Liu Y, Li YB, Cui J, Liu YY, Cheng JM, Karagi D, 2012. Optimisation of sonication conditions to enhance seed vigour in switchgrass (Panicum virgatum). Seed Sci. Technol. 40:404-12.

Christopher J, Christopher M, Jennings R, Jones S, Fletcher S, Borrell A, Manschadi AM, Jordan D, Mace E, Hammer G, 2013. QTL for root angle and number in a population developed from bread wheats (Triticum aestivum) with contrasting adaptation to water-limited environments. Theor. Appl. Genet. 126:1563-74.

Colmer TD, Greenway H, 2011. Ion transport in seminal and adventitious roots of cereals during $\mathrm{O}_{2}$ deficiency. J. Exp. Bot. 62:39-57.

Crawford RMM, 1977. Tolerance of anoxia and ethanol metabolism in germinating seeds. New Phytol. 79:511-7.

El-Hendawy SE, Sone C, Ito 0, Sakagami JI, 2011. Evaluation of germination ability in rice seeds under anaerobic conditions by cluster analysis. Res. J. Seed Sci. 4:82-93.

Fausey NR, McDonald MB, 1985. Emergence of inbred and hybrid corn following flooding. Agron. J. 77:51-6.

Guglielminetti L, Busilacchi HA, Perata P, Alpi A, 2001. Carbohydrateethanol transition in cereal grains under anoxia. New Phytol. 151:607-12.

Hamonts K, Clough TJ, Stewart A, Clinton PW, Richardson AE, Wakelin SA, 0'Callaghan M, Condron LM, 2013. Effect of nitrogen and waterlogging on denitrifier gene abundance, community structure and activity in the rhizosphere of wheat. FEMS Microbiol. Ecol. 83:568-84.

Hossain MA, Uddin SN, 2011. Mechanisms of waterlogging tolerance in wheat: morphological and metabolic adaptations under hypoxia or anoxia. Aust. J. Crop Sci. 5:1094-101.

Hsu FH, Lin JB, Chang SR, 2000. Effects of waterlogging on seed germination, electric conductivity of seed leakage and developments of hypocotyl and radicle in sudangrass. Bot. Bull. Acad. Sinica 41:267-73.

ISTA (International Seed Testing Association), 2004. International rules for seed testing. International Seed Testing Association, Bassersdorf, Switzerland.

Kirmizi S, Bell RW, 2012. Responses of barley to hypoxia and salinity during seed germination, nutrient uptake, and early plant growth in solution culture. J. Plant Nutr. Soil Sci. 165:630-40.

Kong FJ, Oyanagi A, Komatsu S, 2010. Cell wall proteome of wheat roots under flooding stress using gel-based and LC MS/MS-based proteomics approaches. Biochim. Biophys. Acta 1804:124-36.

Li C, Jiang D, Wollenweber B, Li Y, Dai T, Cao W, 2011. Waterlogging pretreatment during vegetative growth improves tolerance to waterlogging after anthesis in wheat. Plant Sci. 180:672-8.

Magneschi L, Perata P, 2009. Rice germination and seedling growth in the absence of oxygen. Ann Bot. 103:181-96.

Menegus F, Cattaruzza L, Mattana M, Beffagna N, Ragg E, 1991. Response to anoxia in rice and wheat seedlings. Changes in the $\mathrm{pH}$ of intracellular compartments, glucose-6-phosphate level, and metabolic rate. Plant Physiol. 95:760-7.

Musgrave ME, Ding N, 1998. Evaluating wheat cultivars for waterlogging tolerance. Crop Sci. 38:90-7.

Pang J, Ross J, Zhou M, Mendham N, Shabala S, 2007. Amelioration of detrimental effects of waterlogging by foliar nutrient sprays in barley. Funct. Plant Biol. 34:221-7.

Pekşen A, Pekşen E, Bozo lu H, 2004. Relationships among some seed traits, laboratory germination and field emergence in cowpea (Vigna unguiculata (L.) Wslp.) genotypes. Pakistan J. Bot. 36:311-20.

Perata P, Guglielminetti L, Alpi A, 1996. Anaerobic carbohydrate metabolism in wheat an barley, two anoxia-intolerant cereal seeds. J. Exp. Bot. 47:999-1006.

Setter TL, Waters I, 2003. Review of prospects for germplasm improvement for waterlogging tolerance in wheat, barley and oats. Plant Soil 253:1-34.

Shiel RS, Holburn S, Adey MA, 1987. The influence of aggregate size and drainage potential on germination of barley seeds in flooded soil. Plant Soil 101:115-21.

Singh DK, Singh V, 2003. Seed size and adventitious (nodal) roots as factors influencing the tolerance of wheat to waterlogging. Aust. J. Agr. Res. 54:969-77.

Steel RGD, Torrie JH, Dickey DA, 1997. Principles and procedures of statistics: a biometrical approach. McGraw Hill, New York, USA.

Sultana R, Vales MI, Saxena KB, Rathore A, Rao S, Rao SK, Mula MG, Kumar MV, 2013. Waterlogging tolerance in pigeonpea (Cajanus cajan (L.) Millsp.): genotypic variability and identification of tolerant genotypes. J. Agr. Sci. (Cambridge) 151:659-71.

Tajbakhsh M, 2000. Relationships between electrical conductivity of imbibed seeds leachate and subsequent seedling growth (viabiliy and vigour) in Omid wheat. J. Agr. Sci. Tech. 2:67-71.

Unger IM, Muzika RM, Motavalli PP, 2010. The effect of flooding and residue incorporation on soil chemistry, germination and seedling growth. Environ. Exp. Bot. 69:113-20. 